\title{
Communication
}

[Comunicação]

\section{Adaptation and evaluation of polymerase chain reaction for Brucella ovis detection in semen, urine and organs of rams experimentally infected}

\author{
[Adaptação e avaliação da reação em cadeia da polimerase para detecção de Brucella ovis \\ em sêmen, urina e órgãos de carneiros infectados experimentalmente] \\ C.N. Nozaki, V.R. Salgado, N.S.C. Lira, O. Augusto Filho, M.G. Dasso, \\ J.M.A.P. Antunes, J. Megid \\ UNESP - Faculdade de Medicina Veterinária e Zootecnia \\ Campus de Botucatu - Distrito de Rubião Junior \\ 18618-000 - Botucatu, SP
}

Brucella ovis is the main cause of a clinical or subclinical disorder characterized by epididymitis and subsequent decrease in fertility in rams (Manterola et al., 2003). Diagnosis of $B$. ovis infection is reached by a combination of clinical examination, isolation of the bacterium and detection of anti-B. ovis antibodies in blood serum (Webb et al., 1980; Xavier et al., 2011). Nowadays, more specific techniques such as Polymerase Chain Reaction (PCR) are used in Brucella spp. detection (Cortez et al., 2001; Manterola et al., 2003; Keid, 2004). The objective of the present study was the adaptation and evaluation of PCR for B. ovis in semen, urine and organs samples collected from experimentally inoculated animals. Results were compared with those of microbiological culture, and the applicability of the technique in routine diagnosis was analyzed.

A lyophilized B. ovis REO 198 strain was obtained at the Centro de Pesquisa Veterinária Desidério Finamor - Eldorado do Sul/RS. The Institutional Ethics and Animal Welfare Commission of the FMVZ/UNESP/Campus de Botucatu approved this study (ethics committee protocol n\# 69/2008). Thirty-one rams, from one to two-year-old, were used. A suspension containing $2 \times 10^{9} \mathrm{CFU} / \mathrm{mL} \quad$ B. ovis was administered, $2 \mathrm{~mL}$ by intrapreputial route and $50 \mu \mathrm{L}$ by intraconjunctival route, simultaneously. After inoculation, blood for serology and urine and semen for bacterial culture and PCR were collected every week. Culture of the samples was carried out on the same day of collection (Brown et al., 1971). A pool of weekly samples of urine and semen of each animal was used in PCR totalizing one monthly sample of semen and urine of each animal.

Animals were euthanized each 15 days until the $4^{\text {th }}$ month and monthly subsequently till one year post challenge, and organs (urinary bladder, lungs, spleen, liver, ampoule, bulbourethral gland, prostate, lymph nodes, epididymis and testicles) were collected. Pools of each organ of every two animals euthanized in each moment were used. Protocols followed by different authors (Cortez et al., 2001; Manterola et al., 2003) were used in the preparation of the samples and in the extraction procedure. PCR sensitivity for semen, urine and organ samples was analyzed by means of a concentrated $B$. ovis suspension at $10^{-1}$, according to McFarland scale. Semen, urine and organ samples were contaminated in order to evaluate the detection threshold. To achieve this aim, $1 \mu \mathrm{g}$ of genomic DNA of each sample was added to $1 \mu \mathrm{L}$ of each bacterial dilution.

Contaminated samples were submitted to the following amplification protocol. Semen, urine (approximately $500 \mu \mathrm{L}$ ) and organs samples (approximately 200 $\mu \mathrm{L}$ ) were thawed and added

Recebido em 31 de março de 2011

Aceito em 12 setembro de 2011

*Autor para correspondência (corresponding author)

E-mail: jane@fmvz.unesp.br 
to $500 \mu \mathrm{L}$ Tris-EDTA (TE) buffer, $\mathrm{pH} \quad 8.0$ (10mM Tris-HCL $\mathrm{pH} 8.0 ; 1 \mathrm{mM}$ EDTA $\mathrm{pH} 8.0)$ for semen and urine and $800 \mu \mathrm{L}$ Tris-EDTA (TE) for organs samples. Semen and urine were incubated at $80^{\circ} \mathrm{C}$ for $10 \mathrm{~min}$. After that, they were centrifuged at $13,000 \mathrm{xg}$ for $15 \mathrm{~min}$. The supernatant was discarded and the sample was washed for 2-3 times, until the supernatant was clear. Extremely creamy semen samples were submitted to up to four washings. After being washed, the precipitate for organs samples was resuspended in $350 \mu \mathrm{L}$ Tris-EDTA (TE) buffer, $\mathrm{pH}$ 8.0, made up of $10 \mathrm{mM}$ Tris- $\mathrm{HCl} \mathrm{pH} 8.0$, $25 \mathrm{mM}$ EDTA, pH 8.0, $100 \mathrm{mM} \mathrm{NaCl}$.

Organs samples were incubated at $80^{\circ} \mathrm{C}$ for $10 \mathrm{~min}$ and added to solution made up of SDS $1 \%$ and $12 \mu \mathrm{L}$ proteinase $\mathrm{K}(20 \mathrm{mg} / \mathrm{mL})$. It was then incubated at $37^{\circ} \mathrm{C}$ for $24 \mathrm{~h}$. The aqueous phase containing nucleic acid was extracted using the phenol/chloroform/isoamyl alcohol method (Cortez et al., 2001). The final pellet was resuspended in $60 \mu \mathrm{L}$ TE, $\mathrm{pH} 8.0$, and incubated at $56^{\circ} \mathrm{C}$ for $30 \mathrm{~min}$.

The amplification procedure was the same for semen, urine and organs samples. Primers were ISP1 and ISP2, designed for the Brucella nucleotide sequence IS 6501 (ISP1 F: 5'GGTTGTTAAAGGAGAACAGC - 3' and ISP2 R: 5'- GACGATAGCGTTTCAACTTG - 3') (Manterola et al., 2003). PCR reaction mix was based on Keid et al. (2007), in a final volume of
$25 \mu \mathrm{L}$. The amplification procedure was carried out as described elsewhere (Manterola et al., 2003). The analysis of the amplified product was carried out by $2 \%$ agarose gel electrophoresis $(w / v)$. For the statistical analysis, samples were classified as positive or negative in PCR and microbiological culture. This was done considering the frequency of occurrence of results for PCR and bacterial culture in the monthly samples. Percentage of association between test results was done using Wilcoxon nonparametric test.

PCR primers ISP1 and ISP2 amplified DNA in samples of semen, urine and organs in dilutions up to $10^{-4}$, except for lymph node and spleen samples, which only showed positive results up to dilution $10^{-3}$. As for the 236 semen samples tested, PCR showed higher sensitivity than culture, detecting 51 positive samples whereas culture detected only 19 samples. In urine samples, sensitivity of the techniques was similar. PCR of the organs showed higher sensitivity than bacterial culture. Statistical analysis showed that tests were independent, and that there was no agreement between microbiological culture and PCR (Table 1). The Table 2 represents the agreement percentage, between PCR and bacterial culture. However, no statistical significant difference was observed between semen and urine samples when the percentage of agreement between the tests was evaluated.

Table 1. Result of microbiological culture and PCR for B. ovis in rams experimentally inoculated with $B$. ovis, according to clinical material

\begin{tabular}{cccc} 
& Semen & Urine & Organs \\
\hline Culture & $19 / 236(8.0 \%)$ & $24 / 236(10.1 \%)$ & $7 / 209(3.3 \%)$ \\
PCR & $51 / 236(21.6 \%)$ & $30 / 236(12.7 \%)$ & $45 / 209(21.5 \%)$ \\
\hline
\end{tabular}

Proportion: number of positives/number of samples

Table 2. Descriptive measures of the agreement percentage of PCR and microbiological culture for semen and urine of rams experimentally infected with $B$. ovis

\begin{tabular}{|c|c|c|c|}
\hline \multirow{2}{*}{ Descriptive measure } & \multicolumn{2}{|c|}{ Type of sample } & \multirow{2}{*}{$\mathrm{P}$ value } \\
\hline & Semen & Urine & \\
\hline Minimum value & $33.3 \%$ & $33.3 \%$ & \\
\hline $1^{\circ}$ Quartile & $61.5 \%$ & $62.5 \%$ & \\
\hline Med & $72.7 \%$ & $75 \%$ & \\
\hline $3^{\circ}$ Quartile & $83.7 \%$ & $100 \%$ & $P>0.05$ \\
\hline Maximum value & $100 \%$ & $100 \%$ & \\
\hline Mean \pm standard deviation & $73 \pm 17.9 \%$ & $76.1 \pm 21 \%$ & \\
\hline
\end{tabular}


Detection threshold in lymph nodes and spleen reached only dilution $10^{-3}$. Some authors reported the presence of inhibiting substances, such as hemoglobin, influencing the reaction (Morata et al., 1998) that could explain the lower detection threshold in these samples compared to the other organs suspensions. Studies on the detection threshold of PCR for B. ovis in organs, semen and urine of sheep were not found in the literature analyzed, except for the report by Saunders et al. (2007) who used multiplex PCR, observing sensitivity equal to $25 \mathrm{CFU}$.

Analytical sensitivity observed in the other organs, semen and urine samples were equal to $3 \times 10^{2} \mathrm{CFU} / \mathrm{mL}$, similar to the results by Amim et al. (2001). Sensitivity of $1.0 \times 10^{\circ} \mathrm{CFU} / \mathrm{mL}$ was observed in pools of semen samples obtained from dogs naturally infected by $B$. canis (Keid, 2007). In the present study, positive results were observed in $8.0 \%$ of the semen samples submitted to isolation and in $21.6 \%$ of the samples submitted to PCR. For urine samples, $10.1 \%$ were positive in isolation and $12.7 \%$ in PCR.

The low percentage of rams showing positive bacteriological results in the present study was similar to the findings of other researchers, who reported that the percentage is always lower than the number of clinically affected or serologically positive rams (Ficapal et al., 1998). The low percentage of isolation was justified by the low sensitivity of modified Thayer-Martin agar for semen culture (Manterola et al., 2003). The results of microbiological culture of infected animals in the present study were lower compared with those of a published report (Biberstein et al., 1963). This difference may be explained by the culture medium used in the trial. The highest percentage of isolation was observed in genital organs (testicles, seminal vesicle, epididymis and bulbourethral gland), demonstrating once more the preference of the bacterium for the reproductive tract. PCR used in semen samples showed higher sensitivity than bacterial culture.

The negative results observed in some samples may be explained by the intermittent shedding of the bacterium in the semen (Paolicchi et al., 2000). Urine culture showed positive frequencies, with some samples negative in PCR, what may be explained by the excess of DNA in the samples tested, a potential PCR inhibitor. PCR sensitivity in semen samples $(21.6 \%)$ was higher when compared with bacterial isolation $(8.0 \%)$, as reported by other authors (Hamdy and Amim, 2002). Different results were reported by some authors using the same primer pairs, with PCR sensitivity equal to $51.9 \%$ (Manterola et al., 2003). PCR sensitivity in urine samples (12.7\%) was almost similar to isolation $(10.1 \%)$, whereas PCR sensitivity in organs was equal to $21.5 \%$. Results found in the present study were similar to those reported by other authors (Cortez et al., 2001). In the present study, PCR detected a greater number of positive samples than microbiological culture, showing that this adapted technique may be a diagnostic alternative in the confirmation of infection, due to prompt diagnosis. Isolation is too timeconsuming, and not practical to be used in routine testing of asymptomatic animals.

Keywords: ram, semen, urine, brucellosis, culture

\section{RESUMO}

O objetivo do estudo foi adaptar e avaliar a PCR para detecção de Brucella ovis e comparar os resultados com aqueles obtidos por cultivo microbiológico do sêmen, urina e dos órgãos de carneiros infectados experimentalmente. Dos 31 animais infectados experimentalmente, amostras de PCR do sêmen apresentaram maior sensibilidade (21,6\%) do que o cultivo (8,0\%). Em amostras de urina, a sensibilidade das técnicas foi semelhante (10,1\% para a cultivo e 12,7\% para PCR). PCR detectou a presença do agente em 21,5\% das amostras testadas, enquanto os órgãos de cultivo detectaram em apenas 3,3\% das amostras. PCR detectou um maior número de amostras positivas do que o cultivo microbiológico.

Palavras-chave: brucelose, cultivo, carneiro, sêmen, urina 


\section{ACKNOWLEDGEMENTS}

To FAPESP ( Fundação de Amparo a Pesquisa do Estado de São Paulo) for the financial support.

\section{REFERENCES}

AMIM, A.S.; HAMDY, M.E.; IBRAHIM, A.K. Detection of Brucella melitensis in semen using the polymerase chain reaction assay. Vet. Microbiol., v.83, p.37-44, 2001.

BIBERSTEIN, E.L.; McGOWAN, O.; KENNEDY, P.C. Epididymitis in rams studies on pathogenesis. Cornell Vet., v.54, p.27-41, 1963.

BROWN, G.M.; RANGER, C.R.; KELLY, D.J. et al. Selective media for the isolation of Brucella ovis. Cornell Vet., v.61, p.265-280, 1971.

CORTEZ, A.; SCARCELLI, E.; SOARES, R.M. et al. Detection of Brucella DNA from aborted bovine foetus by polymerase chain reaction. Aust. Vet. J., v.79, p.500-501, 2001.

FICAPAL, A.; JORDANA, J.; BLASCO, J.M. et al. Diagnosis and epidemiology of Brucella ovis infection in rams. Small Ruminant Res., v.29, p.13-19, 1998.

HAMDY, M.E.; AMIM, A.S. Deteccion of Brucella species in the milk of infected cattle, sheep, goats and camels by PCR. Vet. J., v.163, p.299-305, 2002.

KEID, L.B. The polymerase chain reaction (PCR) for the detection of Brucella spp. in whole-blood of naturally infected dogs. Arq. Inst. Biol., v.71, p741-749, 2004.
KEID L.B. Diagnosis of canine brucellosis: comparison between serological and microbiological tests and a PCR based on primers to $16 \mathrm{~S}-23 \mathrm{~S}$ rDNA interspacer. Vet. Res. Commun., v.31, p.951-965, 2007.

MANTEROLA, L.; TEJERO-GARCES, A.; FICAPAL, A. et al. Evaluation of a PCR test for the diagnosis of Brucella ovis infection in semen samples from rams. Vet. Microbiol., v.92, p.65$72,2003$.

MORATA, P.; QUEIPO-ORTUNO, M.I.; COLMENERO, J.D. Strategy for optimizing DNA amplification in a peripheral blood PCR assay used for diagnosis of humam brucellosis. $J$. Clin. Microbiol., v.36, p.2443-2446, 1998.

PAOLICCHI, F.A.; CASARO, P.A.; GIMENO, E.J. et al. Antiesperm response in rams experimentally infected with Brucella ovis. Small Ruminant. Res., v.36, p.7-15, 2000.

SAUNDERS, V.F.; REDDACLIFF, L.A.; BERG, T. et al. Multipelx PCR for the detection of Brucella ovis, Actinobacillus seminis and Histophilus somni in ram semen. Aust. Vet. J., v.85, p.72-77, 2007.

WEBB, R.F.; QUINN, C.A.; COCKRAM, F.A. et al. Evaluation of procedures for the diagnosis of Brucella ovis infection in rams. Aust. Vet. J., v.56, p.172-175, 1980 .

XAVIER, M.N.; SANT'ANNA, F.M.; SILVA, T.M.A. et al. A comparison of two agar gel immunodiffusion methods and a complement fixation test for serologic diagnosis of Brucella ovis infection in experimentally infected rams. Arq. Bras. Med. Vet. Zootec., v.63, p.1016-1021, 2011. 